\title{
The Textbook Dilemma: Digital or Print? Evidence from a Selected US University
}

\author{
Kavita Chavali ${ }^{1}$, Raghava R. Gundala ${ }^{2}$ \\ ${ }^{1}$ Dhofar University, Salalah, Sultanate of Oman, \\ ${ }^{2}$ University of Wisconsin-Parkside, Kenosha, Wisconsin, USA
}

\begin{abstract}
The increasing price of textbooks impacts students of higher education in the world. E-textbooks are becoming popular among students at all levels of education, especially at the university level. There is a shift in students reading habits and preferences towards e-textbooks. This growing trend has encouraged researchers to gather information about students' experiences, attitudes, and perceptions regarding using e-textbooks and their impact on the learning process. This study surveys undergraduate students in a small mid-western university in the USA. Data is collected from students studying four different colleges. A total of 346 questionnaires were collected. The findings revealed that $34.39 \%$ of the current users in the total sample do not want to use e-textbooks in the future. The predominant factors influencing the adoption of e-textbooks over print textbooks are cost, learning and engagement in interactive exercises, convenience, and flexibility. The study suggests some initiatives that educators, technology experts, designers, and universities can take for more students to adopt a digital version of textbooks to solve the problem of affordability.
\end{abstract}

Keywords - textbook, e-textbook, learning, affordability, prices, engagement.

DOI: 10.18421/TEM111-30

https://doi.org/10.18421/TEM111-30

Corresponding author: Kavita Chavali, Dhofar University, Salalah, Sultanate of Oman. Email: kchavali@du.edu.om

Received: 25 October 2021.

Revised: 31 January 2022.

Accepted: 05 February 2022.

Published: 28 February 2022.

(c))BY-NC-ND (C) 2022 Kavita Chavali \& Raghava R. Gundala; published by UIKTEN. This work is licensed under the Creative Commons Attribution-NonCommercial-NoDerivs 4.0 License.

The article is published with Open Access at https://www.temjournal.com/

\section{Introduction}

The prices of college print textbooks have increased, impacting the affordability and access to higher education. The textbooks cost a quarter of the average tuition for state universities and three-fourths the average tuition at community colleges (Source: US Government Accountability Office, 2013). According to a survey conducted in the US in 2020, $66 \%$ of students could not buy textbooks and course materials because of increased prices. In addition, $25 \%$ of students worked extra hours to pay for their books and materials, and 19\% of students indicated the cost of materials and books directly influenced their decision on what classes to take [1]. Due to the high costs of textbooks, students either delayed buying the textbook or were unable to purchase the required textbooks, which resulted in them failing in courses. In addition, students did not register for some classes or withdraw from a class because they could not bear the costs. This may, in the future, result in fewer graduates pursuing higher education and most of them unable to complete their college degrees on time, impacting the US international economic competitiveness. As a result, there is a decline in publishers' revenue in the higher education sector, from $\$ 4.5$ billion in 2015 to $\$ 3.23$ billion in 2019. The average cost per student in 2020 on a print textbook is $\$ 84$ against an e-textbook which is $\$ 38$. The price of print textbooks increases by $12 \%$ with every new edition, which comes out once in 3 to 4 years.

The problems caused by the increase in the costs of textbooks need a practical solution. However, the solutions may be quite challenging due to publishing industry practices impacting prices. They are:

- The dominance of fewer book publishers - five textbook companies account for over $80 \%$ of the $\$ 9$ Billion publishing market [2].

- Instructors are given free copies of textbooks and related materials for promoting the textbook, which is already reflected in the textbook price, causing its price to escalate. 
- Publishers market the print textbooks and materials in "bundles," which cannot be bought separately

The total textbook sales revenue in 2019 in the US is $\$ 26$ billion, out of which print books generated $74.7 \%$ of the total revenue. According to the survey conducted by the Pew Research Center in 2019 on Americans' reading habits, $72 \%$ of adults read a book in the last 12 months, $37 \%$ claim that they read only a book in print, $7 \%$ claim that they read only an ebook. All efforts are made to look for practical solutions to make education and instructional material more affordable by transitioning into digital textbook mode. [3] observed mixed results and a big challenge to move from print textbooks to etextbooks. In this context, there is a need to look for less expensive alternative solutions and examine the students' experiences, attitudes, and perceptions about using digital textbooks.

\subsection{Purpose of the Study}

This study surveys students from different colleges (Social Sciences, Human Sciences, Management, and Engineering courses) of a small mid-western university in the US. The study gathers information about students' experiences, attitudes, and perceptions regarding e-textbooks and their impact on learning. With the increase in prices of print textbooks and the usage and availability of etextbooks, researchers felt the need to explore how students perceive and interact with these digital resources. The findings of this survey may contribute to the growing literature on the users' perception, attitude, and practices concerning print or digital versions of textbooks and a way to resolve the rising costs of textbooks and other course materials by going digital.

\subsection{Survey Administration}

The data was collected during Spring 2019 as a class project for the "Marketing Research" course. Students were asked to design an instrument and collect data from their peers for a month. The questionnaire consisted of a 'qualifying question' to eliminate duplication of respondents as there might be a possibility that multiple students might approach the same student for responses. The responses of students were collected voluntarily. Students were assured that their grades would not be affected negatively due to not participating in the survey. A total of 482 questionnaires were collected. The questionnaires were verified for completeness and data accuracy to eliminate unfilled questionnaires. One hundred thirty-six questionnaires were incomplete and deleted, leaving the total number (n) to 346 .

\section{Literature Review}

The existing literature on the usage of textbooks focuses on aspects like technology, cost, student's attitude, and preferences. The preference of reading format in academic courses among students is consistent worldwide. Print textbooks have always remained the first choice and have been an integral part of the curriculum. Regardless of students' familiarity with print textbooks, it is observed that there is intense competition from a digital version of the textbooks.

[4] in their study, more than $62.5 \%$ of the students believed that there would be a growing demand for etextbooks. This is because students now are primarily online, using social media, and conversant in using electronic devices. According to a Pew Research Study published in 2015, 92\% of adolescents go online daily using their phones and other electronic devices in the US. In the studies in the past, the findings regarding students' preferences of etextbook are contrasting. The studies illustrate that students preferred print textbooks over e-textbooks [5], [6], and the studies done in the US justify that etextbooks are preferred over traditional print textbooks [7]. Currently, there is a growing demand for e-textbooks. [8].

E-textbook is "a digital object with textual content, which arises from integrating features such as search, hypertext, bookmarks, annotations, highlights, multimedia objects, and interactive tools" [9]. Etextbooks are used for educational purposes and contain interactive materials [10]. E-textbooks have the uniqueness of catering equally to all students with different learning abilities [11]. E-textbooks have improved usability and functionality and offer a better experience than print textbooks [12]. Because of this, there is a perception that e-textbooks in the future may replace print textbooks because of interaction embedded in them, which helps provide enhanced learning. In the future, students may use etextbooks at all levels, from school to higher education. There seem to be a shift in student preferences based on the current trend of usage of etextbook.

Nielsen Research Company, in the year 2015 has, surveyed US Higher Education and found the reasons why educators wanted to introduce e-textbooks in their courses. $49 \%$ of educators think that there is an improvement in the overall student comprehension and understanding of the course material, $46 \%$ believe that the students are better engaged with the course, $34 \%$ think they could more easily achieve learning outcomes, $20 \%$ believe that the digital version of a textbook is effective in accommodating different levels of students and $31 \%$ of them found students were more involved with the course with the 
help of e-textbooks and online study guides as interactive tools. [13] in his research, he ascertained that the younger students in the age bracket of 15-30 years with good computer skills preferred etextbooks compared to the older generation. According to the survey conducted in the US by [14], it is found that those who are in the age bracket of 25-29 and frequent internet users are more inclined towards using an e-textbook. The older students in the age bracket of 40 and above experience a learning curve using e-textbooks, unlike youngsters.

\section{E-Text Book and Learning}

The famous Chinese proverb, "I hear, and I forget. I see, and I remember. I do and I understand," can be applied to e-textbooks which helps the students to hear, see, and do, which can be embedded into a textbook to increase student understanding. Currently, e-textbooks are designed not as mere textbooks but as interactive instructional tools to reinforce student understanding. In addition, Etextbooks are slowly becoming user-friendly, making them easy to use and taking notes later exported to any text editor [15].

[16] develop a model and identify the variables that affect the usage of e-textbook, which are accessibility, cognitive factors that focus on awareness, experience, and attitude towards using etextbook, competency in handling and using technology, and finally, use and convenience-the content, accessibility, and readability as the critical factors for an e-textbook to be effective. But contrarily, [17] indicate that the users learned better when they read in print, and two-thirds of surveyed would prefer to print the contents from an etextbook.

[18] justify that preference and usage of e-textbook are based on the student's academic discipline; for example, users of non-business majors like medical sciences and technology found reading e-textbooks helpful and more manageable than a business major students. In addition, students believe that they engage more with e-textbooks, such as highlighting in customized formats resulting in better learning. On the other hand, the students who opted for print format agree that they are more likely to revisit readings in print format than e-textbook. Keeping these mixed reactions in the past studies, researchers have made an effort to study the attitudes and perceptions towards the usage of e-textbook by students as an alternative to a print textbook.

\section{Analysis and Findings}

The study gathers student experiences and perceptions regarding e-textbooks from different colleges in a small mid-western university. A questionnaire is administered to total sample size is 346. Table 1 shows the survey results of the demographics of the sample and their perception and attitude towards using e-textbooks in the past and the future. The sample constituted $53.76 \%$ male and $46.24 \%$ female.

Table 1. Past and future use of e-textbook across demographics

\begin{tabular}{|c|c|c|c|c|c|c|}
\hline \multicolumn{2}{|c|}{$\begin{array}{c}\text { Demographic } \\
\text { Variable }\end{array}$} & \multicolumn{2}{|c|}{$\begin{array}{c}\text { Past / } \\
\text { Current use } \\
\text { of } \\
\text { e-textbook }\end{array}$} & \multicolumn{2}{|c|}{$\begin{array}{c}\text { Future } \\
\text { use of } \\
\text { e-textbook }\end{array}$} & \multirow{2}{*}{ 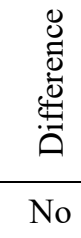 } \\
\hline & & Yes & No & Yes & No & \\
\hline \multirow{3}{*}{$\underset{\dot{0}}{\frac{\dot{\theta}}{0}}$} & Male & 183 & 3 & 123 & 63 & +60 \\
\hline & Female & 158 & 2 & 99 & 61 & +59 \\
\hline & Total & 341 & 5 & 222 & 124 & +119 \\
\hline \multirow{5}{*}{ 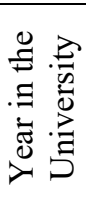 } & Freshman & 35 & 2 & 28 & 9 & +7 \\
\hline & Sophomore & 55 & 0 & 37 & 18 & +18 \\
\hline & \begin{tabular}{|l} 
Junior \\
\end{tabular} & 124 & 2 & 82 & 44 & +42 \\
\hline & Senior & 127 & 1 & 75 & 53 & +52 \\
\hline & Total & 341 & 5 & 222 & 124 & +119 \\
\hline \multirow{5}{*}{ 总 } & CAHSS & 50 & 2 & 36 & 16 & +14 \\
\hline & CEHHS & 96 & 1 & 58 & 39 & +38 \\
\hline & $\mathrm{COM}$ & 127 & 1 & 86 & 42 & +41 \\
\hline & CSTEM & 68 & 1 & 42 & 27 & +26 \\
\hline & Total & 341 & 5 & 222 & 124 & +119 \\
\hline \multirow{6}{*}{ 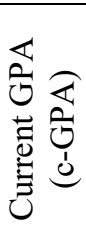 } & Below 2.00 & 1 & 0 & 0 & 1 & +1 \\
\hline & \begin{tabular}{|l|}
$2.00-2.50$ \\
\end{tabular} & 11 & 1 & 10 & 2 & +1 \\
\hline & $2.51-3.00$ & 73 & 1 & 47 & 27 & +26 \\
\hline & $3.01-3.50$ & 164 & 1 & 105 & 60 & +59 \\
\hline & $3.51-4.0$ & 92 & 2 & 60 & 34 & +32 \\
\hline & Total & 341 & 5 & 222 & 124 & +119 \\
\hline
\end{tabular}

Source: Primary data

CAHSS = College of Arts, Humanities and Social Sciences CEHHS = College of Education, Health and Human Sciences $\mathrm{COM}=$ College of Management

CSTEM = College of Science, Technology, Engineering and Mathematics

Table 1 as per the study's findings, $98.55 \%$ of the sample used an e-textbook in the past. However, $34.39 \%$ of the total sample did not want to use the digital version in the future. The usage was purely situational, and they probably were not happy with the experience. The users' previous use of e-books had no bearing on the overall preference for e-books [19]. $10.40 \%$ of the sample are from first-year students, $15.89 \%$ are from Sophomore, $36.41 \%$ are from Junior year, and $36.99 \%$ are from Senior year. The sample has students from all colleges. $16.47 \%$ of the sample from College of Arts and Humanities, 
$28.03 \%$ from College of Education, Health and Human Sciences, $36.99 \%$ of the sample from College of Management, and 19.94\% from the sample from College of Management Science, Technology, Engineering, and Mathematics. The sample constituted of $0.28 \%$ of students with a current cGPA of Below 2, 3.46\% of the sample with c-GPA of $2.00-2.50,21.38 \%$ of the sample with c-GPA 2.51-3.00, $48.38 \%$ of the sample with c-GPA of 3.01 $-3.50,27.16 \%$ of the sample with current c-GPA of $3.51-4.00$.

Table 2. Past and Future use of e-textbook across selected demographics

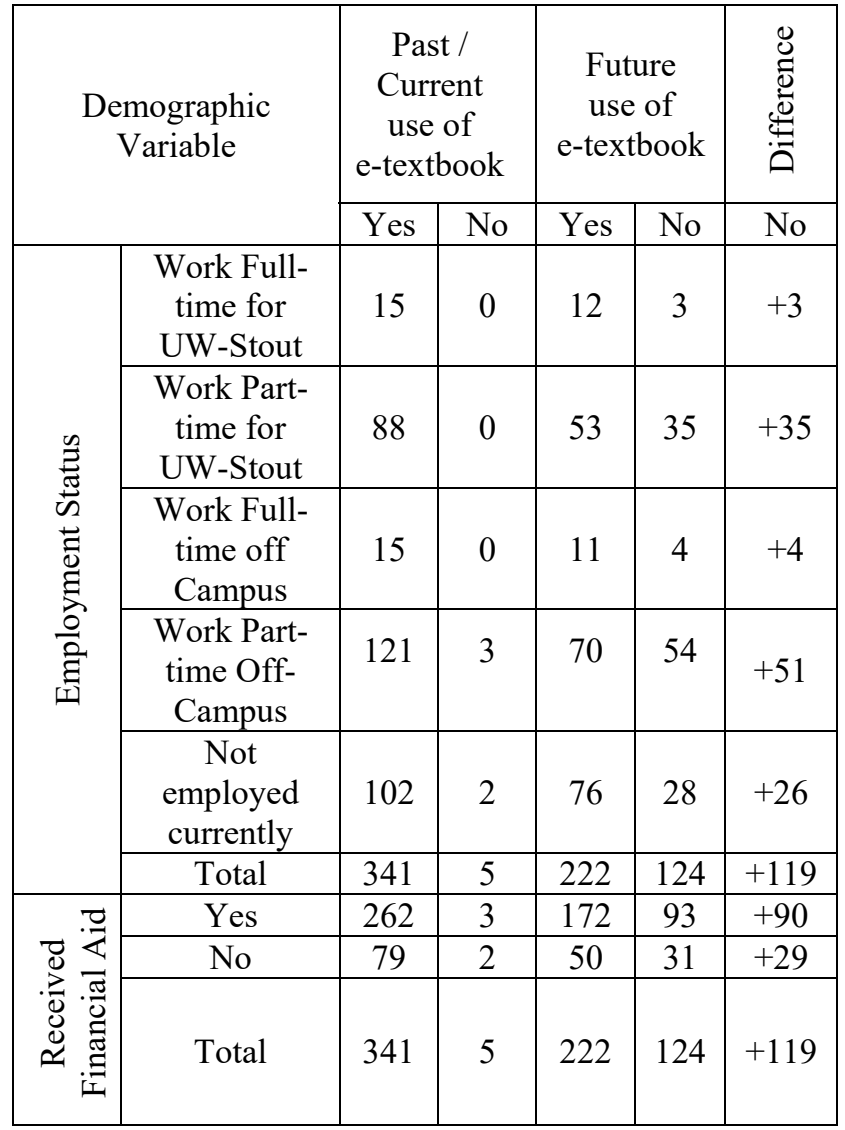

Source: Primary data

Table 2 shows the demographics - employment status of the sample. $4.33 \%$ of the sample work fulltime on the campus, $25.43 \%$ work part-time on the campus, $4.33 \%$ work full-time off-campus, $35.83 \%$ work part-time off-campus, and $30 \%$ of the sample are not employed currently. In addition, $76.58 \%$ of the sample received financial aid, and $23.41 \%$ did not receive any financial assistance.
Table 3. Perception \& Attitude of users towards adopting e-textbook /print textbook

\begin{tabular}{|l|c|c|}
\hline \multicolumn{1}{|c|}{ Reasons } & e-textbook & $\begin{array}{c}\text { print } \\
\text { textbook }\end{array}$ \\
\hline Focus and Concentration & 19 & 327 \\
\hline $\begin{array}{l}\text { Length of Reading } \\
\text { (Short/ Long) }\end{array}$ & 139 & 207 \\
\hline Cost / Affordability & 339 & 7 \\
\hline $\begin{array}{l}\text { Convenience and } \\
\text { Flexibility }\end{array}$ & 305 & 41 \\
\hline $\begin{array}{l}\text { Highlighting \& } \\
\text { Annotation }\end{array}$ & 336 & 10 \\
\hline $\begin{array}{l}\text { Learning Engagement in } \\
\text { the form of Interactive } \\
\text { exercises }\end{array}$ & 319 & 27 \\
\hline $\begin{array}{l}\text { Fatigue / Tiredness of } \\
\text { eyes }\end{array}$ & 198 & 149 \\
\hline Accessibility & & \\
\hline
\end{tabular}

Source: Primary data

Table 3 lists the user choice and preference of etextbook vs. print textbook. The factors selected to check the perception and attitude of users of textbook/e-textbook are taken from the available literature. When it comes to focusing and concentrating traditional textbooks in print, users find it desirable over e-textbook, which is in line with [20]. However, reading a digital version of the textbook on screen led to lower recall and performance [21].

The length of reading or time spent reading is short; students possibly preferred e-textbook compared to print textbooks. Contrastingly, users may prefer a print textbook when spending long hours reading academic textbooks. It is in line with the findings of [22]. In addition, there are contrasting findings by [23], who justify in their study that users who owned e-textbooks read on average twice as many books as those who read-only in print because of convenience. To inculcate the long hours of reading online, some of the coping strategies adopted are using the highlight feature, copy and pasting for future review, customizing font sizes to suit the user requirement, and using a laptop with a big screen to avoid strain on the eyes.

Convenience and flexibility are the user's ability to easily carry and use irrespective of the time and location and access the text in its entirety or scrolling. In terms of convenience and flexibility in terms of portability, a digital textbook is preferred by the users compared to a print textbook. In contrast to this, [24], in their study, argue that the navigation in an e-textbook (like refresh rate) is quite challenging compared to a print version. 
In their study, [25] justify that both the publishers and users benefitted from e-textbooks. The publishers benefitted by achieving economies of scale. The cost of an e-textbook for the students dropped by 15-20 times compared to a print textbook. In addition, users preferred e-textbooks regarding affordability compared to print textbooks.

Users preferred e-textbook in terms of highlighting and annotation. It is unique traditionally in the print textbooks where the users keep coming back to where they have left. [26] observed that students hardly used the feature of highlighting option in etextbook. Research suggests that annotating a text while reading can improve student learning and retention. [27] argued that the user is given the flexibility to edit the content in an e-textbook like font size. This customization increases the usability of an e-textbook to a great extent.

Learning engagement of the student is believed to be one of the most important factors by learners in the literature. In the study, e-textbook is the preferred choice of students for learning engagement. The users responded that they had better comprehension and understanding from an e-textbook probably because of the learning engagement and interaction experience, which are in line with the study of [28]. However, users' experience with e-textbooks may be unique and not typically associated with printed text [29]. On the other hand, contrastingly, [30] argues that users reading in the digital medium are constrained to mentally reconstruct what was read since students performed better reading in print.

The users found the digital version of the textbook to cause fatigue and tiredness of the eyes. In addition, e-textbooks are uncomfortable and difficult to read using gadgets with small screens like mobile phones. This problem, to some extent, can be solved by audiobooks or read-aloud textbooks.

Accessibility means availability of e-textbook online and offline, availability of the internet to download and users experience, and e-textbook functionality in various gadgets like phones, laptops, etc. The ability to download an e-book for offline use was one of the participants' most frequently rated features [31]. Users indicated a mixed response as accessibility probably could be because print textbooks can be borrowed from a library and accessible to all. Still, users with financial constraints may not be accessible to one or may not have the required gadget to get its full functionality. The study done by [32] argues that the user acceptance rate for e-textbooks is slow because of the time taken for loading and flipping pages.

\section{Limitation of the Study}

The data for the study is collected in the year 201920 , which can be a significant limitation. The pandemic played a substantial role in shifting from face-to-face classes to online or remote classes. This could affect the students' responses and findings of the study, which is a significant limitation. According to the Association of American Publishers, the average student spending on textbooks and course materials during the pandemic during the fall semester of 2020 dropped by $7 \%$ compared to the same term last year. The per capita units purchased increased by $3 \%$ in 2020-21. Still, the overall spending on textbooks and course materials has declined because of the adoption of less expensive digital versions.

\section{Conclusion and Implications}

Understanding the experience, perception, attitudes, and preferences towards students' textbooks through a survey will help us know the reasons for the transition from print to digital. Despite the growing demand for the digital version, overall, users gave preference to print textbooks. With the increasing digital version of textbooks, users who find it easy and helpful to learn from print texts have to pay a premium to print course materials and may be at an economic disadvantage compared to their peers. According to the findings, the prime reason why users want to change into the digital version of a textbook from print is because of its costeffectiveness. Therefore, there should be a balance between print and digital formats competing with the cost factor, user engagement and learning, and convenience. This gives an opportunity and scope for initiatives to be taken by technology experts, educators, and universities for students to adapt to the digital version of textbooks.

The technology experts, content developers, and designers can develop innovative ways to improve the usability and likeability of e-textbook for users without increasing the price. It would be helpful if designers help users acquire knowledge to use digital textbooks by giving clear instructions on the usage, providing supplementary information, and providing a specific methodology for their use. The increase of e-textbooks can motivate library users to try etextbooks, providing workshops and particular instructions on using or accessing e-books. Educators base their assignments and projects based on etextbooks. Educators need to be aware of student attitudes towards textbook options before adopting a print or a digital version. Educators need to be sensitive about the affordability and advantages of a digital version of textbooks and make the digital 
textbook format more relevant and necessary for classroom assignments, discussions, learning, and tests. The affordability offered by the e-textbook may sometimes have to bear the potential costs. The educators have a role in creating a smart learning environment where the learning is directed to digital learners' needs. The million-dollar question remains, which is; Are students willing to give up the benefits of a print textbook to have the affordability and ease offered by digital texts?

\section{References}

[1]. Hanson, M.(2021). Average Cost of College Textbooks. Retrieved from: https://educationdata.org/average-cost-of-college-

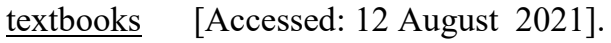

[2]. Allen, N. (2013). The future of digital textbooks. American Association of State Colleges and Universities. Retrieved from: https://www.aascu.org/workarea/downloadasset.aspx? id=6308 [Accessed: 12 August 2021].

[3]. Brown, R. (2013). A survey of professor acceptance and use of e-textbooks in higher education. Contemporary Issues in Education Research (CIER), 6(2), 219-222.

[4]. Kouis, D., \& Konstantinou, N. (2014). Electronic textbooks advantages and challenges for the Hellenic higher education and publishing community. Library Review.

[5]. Abuloum, A., Farah, A., Kaskaloglu, E., \& Yaakub, A. (2019). College Students' Usage of and Preferences for Print and Electronic Textbooks. International Journal of Emerging Technologies in Learning (iJET), 14(7), 80-97.

[6]. Majid, S., Chenqin, Y., Chang, Y., \& Zilu, C. (2019). Perceptions and e-book use behavior of university students. International Journal of Digital Society, 10(4), 1534-1540.

[7]. Abuloum, A., Farah, A., Kaskaloglu, E., \& Yaakub, A. (2019). College Students' Usage of and Preferences for Print and Electronic Textbooks. International Journal of Emerging Technologies in Learning (iJET), 14(7), 80-97.

[8]. Foasberg, N. M. (2014). Student reading practices in print and electronic media. College \& Research Libraries, 75(5), 705-723.

[9]. Vasileiou, M., Hartley, R., \& Rowley, J. (2012). Choosing e-books: a perspective from academic libraries. Online Information Review, 36(1), 21-39.

[10]. McKnight, C., \& Dearnley, J. (2003). Electronic book use in a public library. Journal of librarianship and information science, 35(4), 235-242.

[11]. Hukill, G. S., Arnold, J. M., \& Klein, J. T. (2017). Reading in the digital age: A case study in faculty and librarian collaboration. College \& Undergraduate Libraries, 24(2-4), 574-594.

[12]. Mulholland, E., \& Bates, J. (2014). Use and perceptions of e-books by academic staff in further education. The Journal of Academic Librarianship, 40(5), 492-499.
[13]. Grenina, A. (2013). Electronic books: content provision and adoption possibilities among users in Latvia. Bibliopolis, 48(2), 32-47.

[14]. Anderson, P. (2020) AAP Reports 23-Percent Increase on US E-Textbooks in Fall Semester.

Retrieved from:

https://publishingperspectives.com/2020/11/aapcourse-materials-spending-report-23-percent-up-etextbooks-usa-covid19/ [Accessed: 06 October 2021].

[15]. Johnston, N., \& Salaz, A. M. (2019). Exploring the reasons why university students prefer print over digital texts: An Australian perspective. Journal of the Australian Library and Information Association, 68(2), 126-145.

[16]. Roesnita, I., \& Zainab, A. N. (2013). The pattern of e-book use amongst undergraduates an Malaysia: A case of to know is to use. arXiv preprint arXiv:1301.5400.

[17]. Ji, S. W., Michaels, S., \& Waterman, D. (2014). Print vs. electronic readings in college courses: Costefficiency and perceived learning. The Internet and Higher Education, 21, 17-24.

[18]. Alfiras, M., \& Bojiah, J. (2020). Printed textbooks versus electronic textbooks: A study on the preference of students of Gulf university in kingdom of Bahrain. International Journal of Emerging Technologies in Learning (iJET), 15(18), 40-52.

[19]. Woody, W. D., Daniel, D. B., \& Baker, C. A. (2010). E-books or textbooks: Students prefer textbooks. Computers \& education, 55(3), 945-948.

[20]. Shepherd, J., \& Arteaga, R. (2014). Social work students and e-books: a survey of use and perception. Behavioral \& Social Sciences Librarian, 33(1), 15-28.

[21]. Li, L. Y., Chen, G. D., \& Yang, S. J. (2013). Construction of cognitive maps to improve e-book reading and navigation. Computers \& Education, 60(1), 32-39.

[22]. Mizrachi, D. (2015). Undergraduates' academic reading format preferences and behaviors. The Journal of Academic Librarianship, 41(3), 301-311.

[23]. Zickuhr, K., Rainie, L., Purcell, K., Madden, M., \& Brenner, J. (2012). Younger Americans' Reading and Library Habits. Pew Internet \& American Life Project.

[24]. Garland, K. J., \& Noyes, J. M. (2004). Computer experience: a poor predictor of computer attitudes. Computers in Human Behavior, 20(6), 823840 .

[25]. Joseph, R. P., \& Jha, S. K. (2015). Digitization, Internet publishing and the revival of scholarly monographs: An empirical study in India. First Monday.

[26]. Johnston, N., \& Ferguson, N. (2020). University students' engagement with textbooks in print and ebook formats. Technical services quarterly, 37(1), 2443.

[27]. Soules, A. (2008). New types of e-books, e-book issues, and implications for the future. The Acquisitions Librarian, 19(3-4), 367-388. 
[28]. Sung, H. Y., Hwang, G. J., Chen, C. Y., \& Liu, W. X. (2019). A contextual learning model for developing interactive e-books to improve students' performances of learning the Analects of Confucius. Interactive Learning Environments, 1-14.

[29]. Hartman, D. K., Morsink, P. M., \& Zheng, J. (2010). From print to pixels: The evolution of cognitive conceptions of reading comprehension. The new literacies: Multiple perspectives on research and practice, 131-164.
[30]. Spires, H. A., \& Estes, T. H. (2002). Reading in web-based learning environments. Comprehension instruction: Research-based best practices, 115-125.

[31]. Nicholas, D., Rowlands, I., Clark, D., Huntington, P., Jamali, H. R., \& Ollé, C. (2008). UK scholarly ebook usage: a landmark survey. Perspectives, 60(4), 311-334.

[32]. Chu, H. (2003). Electronic books: viewpoints from users and potential users. Library Hi Tech, 21(3), 340346. 